\title{
CrimRxiv
}

\section{Frequent Drug Use and Negative Employment Outcomes among the Criminally Active}

Paul E. Bellair, Mike Vuolo, Eric G. LaPlant

Published on: Jul 05, 2021

DOI: $10.21428 / \mathrm{cb} 6 a b 371.0177 \mathrm{~d} 646$

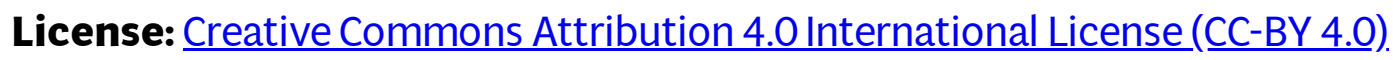


